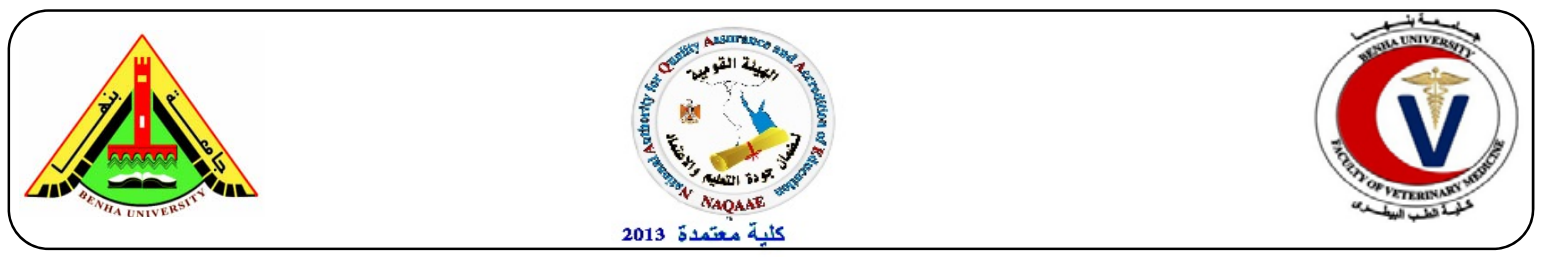

\title{
Ameliorative effect of novel nanocomposite: basic curcumin nanoparticles modified with basic nano black seeds (nigella sativa) and calcium ascorbate on metabolic changes in experimentally induced tumor in female mice.
}

\author{
Omayma A. Ragab Abou Zaid, Abdel Fatah. M. Badwi, Nora Abd Elmohsen El Sayed.
}

Department of Biochemistry, Faculty of Veterinary Medicine, Benha University, Egypt.

\section{A B S T R A C T}

The ameliorative effect and antitumor activity of basic curcumin nanoparticles modified with basic nano black seeds (nigella sativa) and calcium ascorbate were evaluated. eighty female mice were divided into 4 equal groups of 20 mice each. Group 1: non - tumor bearing mice (NTBM). Group 2: tumor bearing mice(TBM). Group 3: NTBM + nanocomposite $(4.750 \mathrm{gm} / \mathrm{kg}$. b.wt /day ), orally for 6 weeks . Group 4: $\mathrm{TBM}+$ nanocomposite $(4.750 \mathrm{gm} / \mathrm{kg}$. b.wt/day $)$, orally for 6 weeks . Blood samples for serum separation and liver tissues specimens were collected from all animal groups three times after 2, 4 and 6 weeks from the onset of treatment. All serum was directly used for determination of ALT and AST activities and urea and creatinine concentrations. Moreover, antioxidants enzymes (catalase, GPX, SOD), GSH and MDA were detected in liver tissue. The obtained results showed significant decrease in catalase, GPX and SOD activities and GSH concentration in liver tissue of tumor bearing mice. Meanwhile, liver MDA, serum transferases(ALT and AST) activities, urea and creatinine concentrations were significantly increased in tumor bearing mice. TBM treated with nanocomposite improve the adverse biochemical changes induced by tumor. So, this nanocomposite has potential benefits in cancer treatment.

Key words: nanocomposite, curcumin nanoparticles, black seed nanoparticles

(http://www.bvmj.bu.edu.eg)

(BVMJ-29(2): 235-244, 2015)

\section{INTRODUCTION}

$\mathrm{C}$ ancer is a group of diseases involving abnormal cell growth with the potential to invade or spread to other parts of the body. It caused about 8.2 million deaths or $14.6 \%$ of all human deaths. The risk of cancer increased significantly with age and many cancers occur more commonly in developed countries. Rates are increasing as more people live to an old age and as lifestyle changes occur in the developing world (Jemal, et al.,2012). Curcumin is one of the most powerful and promising chemopreventive and anticancer agent. Curcumin act as a potent cancer preventing agent by blocking the nuclear factor kappa B (Sajithlal, et al.,1998). Also, Curcumin loaded poly (D, L-lactic-co-glycolic acid)
PLGA nanoparticles has enhanced cellular uptake, and increased bioactivity in vitro and superior bioavailability in vivo over curcumin (Anand, et al., 2010). Black seed (nigella sativa) oil and its main constituents are extensively described to protect several organs against oxidative damage depending on its high antioxidant activity (Mansour, et al.,2002). The active principle fatty acids derived from $N$. sativa, completely inhibited the growth of Ehrlich ascites carcinoma and Dalton's lymphoma ascites cells (Salomi, et al.,1992). Other important and interesting study showed that nigella sativa and its constituents Thymoquinine (TQ) shows role in cancer prevention via inactivation and activation of molecular pathways (Rahmani, et al.,2014). Also, 
Ethanol extract of nigella sativa seeds can generate antioxidants, possess antitumor activity, and ameliorate and prolong the life span of mice bearing Ehrlich ascitic tumor (Musa, et al., 2004). Ascorbate (vitamin C) is implicated in preventing cancer due to its ability in scavenging free radicals and carcinogens maintaining the integrity of connective tissue and improving maintaining the integrity of connective tissue and improving immunocompetence and resistance to cancer (Cameron, et al.,1979). Adequate vitamin $\mathrm{C}$ intake is important to prevent nutrient deficiencies and maintain antioxidant levels so the antitumor defense system keeps working effectively (Kulcsar, 2003). If cancer become established, evidence suggests that vitamin $\mathrm{C}$ may selectively kill cancer cells via production of hydrogen peroxide (Chen, et al.,2005), encapsulate tumors with a collagen wall to prevent metastasis (Cameron, et al.,1979), promote macrophage function and removal of cancer cells (Fiumara, et al.,1997) and (Kaminogawa., et al,2004). Accordingly, the antitumor effect of novel nanocomposite: basic curcumin nanoparticles modified with basic nano black seeds (nigella sativa) and calcium ascorbate on metabolic changes in experimentally induced tumor in female mice were evaluated.

\section{MATERIALS AND METHODS}

\subsection{Animals}

Eighty Australian females albino mice, $12-$ 14 weeks old and weighting $25-30$ gm were used in this study.Mice was obtained from the research institutes of ophthalmology, Giza, Egypt . The animals were housed in separate metal cages, fresh and clean water was supplied ad-libtium through specific nipple. Mice were kept at a constant environmental and nutritional condition throughout the period of the experiment in special animal room at national cancer institute, Egypt.

\subsection{Ehrlich Ascites carcinoma cells}

A line of Ehrlich Ascites carcinoma (EAC) cells was supplied from national cancer institute, Cancer Biology Department, Egypt.

\subsection{Tumor induction}

Solid tumors were induced by intramuscular inoculation of each mice with $0.2 \mathrm{ml}$ of EAC, which contained $2.5 \times 10^{6}$ viable EAC cells, in the right thigh of the lower limb of each mouse. The tumor developed and become palpable in all injected animals at $(7-10)$ days post tumor inoculation.

\subsection{Chemicals:}

Basic nano curcumin and nano black seed were purchased from sigma Aldrich (sigma, USA) company. Vitamin C was purchased from El - Gomhoria Chemicals Company, Egypt.

Nanocomposite compound: The novel nanocomposite was composed of Basic nano curcumin $3.0 \mathrm{gm}+$ nano black seeds $6.0 \mathrm{gm}+$ calcium ascorbate $1.0 \mathrm{gm}$.

\subsection{Experimental design}

Eighty female mice were divided into 4 groups each one contains 20 mice placed in individual cages and classified as follows: G 1: NTBM. G 2: TBM. G 3: NTBM+ nanocomposite $\quad(4.750 \mathrm{~g} / \mathrm{kg}$ b.wt/day), orally for 6 weeks. G 4: TBM +nanocomposite (4.750 g / kg b.wt/day), orally for 6 weeks.

\subsection{Sampling}

Blood samples and liver tissues specimens were collected from all animal groups by decapitation at 2, 4 and 6 weeks from the onset of treatment in dry and clean tubes and serum was separated by centrifugation at 3000 r.pm for 15 minutes .The clear serum was aspirated by Pasteur pipette and received in dry sterile sample tube, processed directly for (ALT and AST) activities determination., then kept in a deep freeze at $-20{ }^{\circ} \mathrm{C}$ until used for subsequent biochemical analysis .All serum were used for determination ALT, AST, urea and creatinine . The liver tissues then 
were obtained in dry and clean plates then kept in a deep freeze $-20 \mathrm{c}$ until used for analysis. All liver tissues used for determination CAT, SOD, GPX, GSH and MDA.

\subsection{Biochemical analysis}

Catalase activity was assayed following the method of Luck (1974). SOD was assayed according to the method of Kakkar et al. (1984). GPX: Glutathione peroxidase was assayed according to the method described by Placer et al. (1966). GPX level was assessed using the method of Paglia and Valentine (1967). Reduced glutathione was determined by method of Moron et al. (1979). MDA: The extent of lipid peroxidation was estimated according to the method of Okhawa et al. (1979). Serum ALT was determined according to the method described by Murray, et al. (1984). Serum AST was determined according to the method described by Murray, et al. (1984). Urea was determined by a colorimetric method as described by Kaplan, et al. (1984). Creatinine was determined according to the method described by Murray, et al. (1984).

\subsection{Statistical analysis}

The statistical analysis was carried out using ANOVA with two factors under significance level of 0.05 for the whole results using SPSS (ver. 22). Data were treated as complete randomization design according to (Steel, et al., 1997). multiple comparison was carried out applying LSD.

\section{RESULTS}

The obtained results presented in tables $(1,2$ and 3 ) showed a significant decrease in liver catalase, SOD, GPX activities and GSH concentration in TBM group compared to the control group. However, significant increase in serum ALT and AST activities and kidney functions (urea and creatinine), in addition the liver MDA concentration in TBM compared to NTBM. In TBM treated with nanocomposite group, a significant increase in the activity of liver antioxidants (catalase, SOD, GPX) and GSH level and decrease in liver MDA concentration, in addition the serum ALT, AST, urea and creatinine were observed when compared with TBM non treated groups.

Table 1: Effect of two weeks oral administration of nanocomposite $(4.750 \mathrm{~g} / \mathrm{kg}$. b.wt $)$ on liver CAT,SOD,GPX and MDA and serum ALT, AST, urea and creatinine in eexperimentally induced tumor female mice

\begin{tabular}{lrlll}
\hline Animal Groups/parameters & \multicolumn{1}{c}{ G1 } & \multicolumn{1}{c}{ G2 } & \multicolumn{1}{c}{ G3 } & G4 \\
\hline CAT Mmol/g. tissue & $78.83 \pm 5.27^{\mathrm{dB}}$ & $78.83 \pm 5.27^{\mathrm{dB}}$ & $53.28 \pm 3.60^{\mathrm{cB}}$ & $38.92 \pm 2.76^{\mathrm{bB}}$ \\
SOD U/g. tissue & $25.56 \pm 3.72^{\mathrm{cB}}$ & $4.77 \pm 0.69^{\mathrm{aA}}$ & $8.40 \pm 0.39^{\mathrm{bA}}$ & $9.55 \pm 0.87^{\mathrm{bA}}$ \\
GPX ng/g. tissue & $30.99 \pm 2.46^{\mathrm{cB}}$ & $16.15 \pm 1.34^{\mathrm{aC}}$ & $17.90 \pm 1.01^{\mathrm{aA}}$ & $23.46 \pm 2.13^{\mathrm{bA}}$ \\
GSH ng/g. tissue & $12.50 \pm 1.07^{\mathrm{dB}}$ & $2.44 \pm 0.69^{\mathrm{aA}}$ & $5.28 \pm 0.58^{\mathrm{bA}}$ & $6.15 \pm 0.41^{\mathrm{cA}}$ \\
MDA Mmol/g. tissue & $52.86 \pm 7.55^{\mathrm{aA}}$ & $163.1 \pm 9.29^{\mathrm{dC}}$ & $116.22 \pm 5.49^{\mathrm{cC}}$ & $75.46 \pm 4.67^{\mathrm{bB}}$ \\
ALT U/L & $46.84 \pm 3.03^{\mathrm{aA}}$ & $97.21 \pm 6.04^{\mathrm{cA}}$ & $70.09 \pm 4.79^{\mathrm{bB}}$ & $70.50 \pm 4.81^{\mathrm{bA}}$ \\
AST U/L & $55.70 \pm 4.01^{\mathrm{aA}}$ & $98.61 \pm 9.32^{\mathrm{cA}}$ & $79.43 \pm 4.90^{\mathrm{bA}}$ & $87.14 \pm 5.72^{\mathrm{bA}}$ \\
Urea mg/dl & $27.09 \pm 1.42^{\mathrm{bA}}$ & $32.39 \pm 2.10^{\mathrm{cA}}$ & $26.09 \pm 1.52^{\mathrm{abA}}$ & $21.77 \pm 1.90^{\mathrm{aA}}$ \\
Creatinine mg/dl & $0.36 \pm 0.03^{\mathrm{aA}}$ & $0.74 \pm 0.03^{\mathrm{cA}}$ & $0.52 \pm 0.02^{\mathrm{bA}}$ & $0.59 \pm 0.03^{\mathrm{bB}}$ \\
\hline
\end{tabular}

$\mathrm{A}, \mathrm{B} \& \mathrm{C}$ : There is no significant difference $(\mathrm{P}>0.05)$ between any two means for the same attribute, within the same row have the same superscript letter. Data are presented as (mean \pm S.E) $\mathrm{S} . \mathrm{E}=$ standard error. 
Table 2: Effect of four weeks oral administration of nanocomposite $(4.750 \mathrm{~g} / \mathrm{kg}$. b.wt) on liver CAT,SOD,GPX and MDA and serum ALT, AST, urea and creatinine in eexperimentally induced tumor female mice

\begin{tabular}{lllll}
\hline Animal groups / parameters & G1 & G2 & G3 & G4 \\
\hline CAT Mmol / g. tissue & $58.35 \pm 3.24^{\mathrm{dA}}$ & $16.01 \pm 1.85^{\mathrm{aA}}$ & $44.90 \pm 2.35^{\mathrm{cA}}$ & $34.32 \pm 2.74^{\mathrm{bA}}$ \\
SOD U / g. tissue & $22.23 \pm 0.94^{\mathrm{dA}}$ & $5.35 \pm 0.46^{\mathrm{aAB}}$ & $10.78 \pm 1.17^{\mathrm{bB}}$ & $15.96 \pm 1.28^{\mathrm{cB}}$ \\
GPX ng / g. tissue & $30.08 \pm 1.73^{\mathrm{dB}}$ & $10.65 \pm 1.10^{\mathrm{aA}}$ & $20.02 \pm 2.15^{\mathrm{bB}}$ & $26.81 \pm 1.88^{\mathrm{cB}}$ \\
GSH ng / g. tissue & $7.46 \pm 0.69^{\mathrm{dA}}$ & $2.23 \pm 0.50^{\mathrm{aA}}$ & $4.74 \pm 0.65^{\mathrm{bA}}$ & $6.28 \pm 0.76^{\mathrm{cA}}$ \\
MDA Mmol / g. tissue & $69.91 \pm 5.30^{\mathrm{bB}}$ & $114.45 \pm 8.62^{\mathrm{dB}}$ & $80.78 \pm 3.00^{\mathrm{cB}}$ & $59.30 \pm 5.88^{\mathrm{aA}}$ \\
ALT U/L & $60.03 \pm 6.39^{\mathrm{aB}}$ & $142.64 \pm 4.99^{\mathrm{dC}}$ & $123.18 \pm 5.40^{\mathrm{cC}}$ & $92.78 \pm 4.13^{\mathrm{bB}}$ \\
AST U/L & $80.27 \pm 4.53^{\mathrm{aB}}$ & $165.84 \pm 7.19^{\mathrm{dC}}$ & $102.56 \pm 3.75^{\mathrm{bB}}$ & $118.92 \pm 3.21^{\mathrm{cB}}$ \\
Urea mg/dL & $40.18 \pm 3.17^{\mathrm{cB}}$ & $61.04 \pm 4.38^{\mathrm{dB}}$ & $31.03 \pm 3.64^{\mathrm{bB}}$ & $24.44 \pm 2.67^{\mathrm{aA}}$ \\
Creatinine mg/dL & $0.85 \pm 0.04^{\mathrm{cB}}$ & $1.15 \pm 0.10^{\mathrm{dB}}$ & $0.62 \pm 0.05^{\mathrm{bB}}$ & $0.51 \pm 0.03^{\mathrm{aA}}$ \\
\hline
\end{tabular}

$\mathrm{a}, \mathrm{b} \& \mathrm{c}$ : There is no significant difference $(\mathrm{P}>0.05)$ between any two means, within the same column have the same superscript letter. A, B \& C: There is no significant difference $(\mathrm{P}>0.05)$ between any two means for the same attribute, within the same row have the same superscript letter. Data are presented as (mean \pm S.E) S.E= standard error.

Table 3: Effect of six weeks oral administration of nanocomposite $(4.750 \mathrm{~g} / \mathrm{kg}$. b.wt $)$ on liver CAT,SOD,GPX and MDA and serum ALT, AST, urea and creatinine in eexperimentally induced tumor female mice :

\begin{tabular}{lllll}
\hline Animal groups / parameters & G1 & G2 & G3 & G4 \\
\hline CAT Mmol / g . tissue & $74.98 \pm 2.56^{\mathrm{dB}}$ & $30.18 \pm 1.11^{\mathrm{aB}}$ & $55.19 \pm 2.40^{\mathrm{cB}}$ & $39.66 \pm 2.17^{\mathrm{bB}}$ \\
SOD U / g . tissue & $27.74 \pm 2.57^{\mathrm{dB}}$ & $7.25 \pm 1.11^{\mathrm{aB}}$ & $24.97 \pm 1.48^{\mathrm{cC}}$ & $15.84 \pm 1.14^{\mathrm{bB}}$ \\
GPX ng / g . tissue & $25.02 \pm 1.91^{\mathrm{bA}}$ & $13.62 \pm 1.07^{\mathrm{aB}}$ & $27.16 \pm 1.60^{\mathrm{bC}}$ & $33.50 \pm 1.51^{\mathrm{cC}}$ \\
GSH ng / g t tissue & $12.16 \pm 0.57^{\mathrm{cB}}$ & $7.10 \pm 0.56^{\mathrm{aB}}$ & $10.41 \pm 0.36^{\mathrm{bB}}$ & $9.93 \pm 0.53^{\mathrm{bB}}$ \\
MDA Mmol / g . tissue & $54.89 \pm 5.93^{\mathrm{aA}}$ & $89.41 \pm 5.76^{\mathrm{bA}}$ & $55.83 \pm 6.99^{\mathrm{aA}}$ & $55.51 \pm 3.50^{\mathrm{aA}}$ \\
ALT U/L & $96.15 \pm 3.17^{\mathrm{bC}}$ & $122.82 \pm 3.62^{\mathrm{dB}}$ & $62.12 \pm 5.76^{\mathrm{aA}}$ & $106.39 \pm 3.66^{\mathrm{CC}}$ \\
AST U/L & $81.47 \pm 3.21^{\mathrm{bB}}$ & $139.22 \pm 5.25^{\mathrm{dB}}$ & $73.00 \pm 2.79^{\mathrm{aA}}$ & $119.7 \pm 2.28^{\mathrm{cB}}$ \\
Urea mg/dL & $58.28 \pm 1.64^{\mathrm{bC}}$ & $61.57 \pm 4.11^{\mathrm{bB}}$ & $62.60 \pm 3.54^{\mathrm{bC}}$ & $32.31 \pm 2.96^{\mathrm{aB}}$ \\
Creatinine mg/dL & $0.99 \pm 0.05^{\mathrm{bC}}$ & $1.31 \pm 0.06^{\mathrm{cC}}$ & $0.99 \pm 0.05^{\mathrm{bC}}$ & $0.69 \pm 0.04^{\mathrm{aC}}$ \\
\hline
\end{tabular}

$\mathrm{a}, \mathrm{b} \& \mathrm{c}$ : There is no significant difference $(P>0.05)$ between any two means, within the same column have the same superscript letter. A, B \& C: There is no significant difference $(P>0.05)$ between any two means for the same attribute, within the same row have the same superscript letter. Data are presented as (mean \pm S.E) S.E $=$ standard error.

\section{DISCUSSION}

The obtained results revealed that, a significant decrease in liver SOD, GPX, CAT activities and GSH concentration with marked significant increase in MDA level were observed in TBM group when compared to control group .These findings were in agreement with (Kumaraguruparan et al., 2002) who found that, the presence of tumor caused disequilibria of the antioxidant defense system. Also, Hayat, (2001) demonstrated that, lipid peroxidation level was significantly increased in blood, liver and tumor tissues of EAC mice when compared with control group. Moreover, Saygili et al., (2003) demonstrated that a decrease in erythrocyte GSH level has been reported in several diseases including malignancies. 
Additionally, a decline in SOD activity was observed in mice bearing Ehrlich carcinoma by (Sahu et al. 1977) who postulated that, the loss of Mn-SOD activity could be due to loss of mitochondria which leads to a decrease in total SOD activity in different tissues of the tumor host. It seems that oxidative damage caused by decreased capacity for $\mathrm{H}_{2} \mathrm{O}_{2}$ elimination is related to suppressed activity of CAT, as well as to suppressed direct antioxidant action of GSH. This was in agreement with the previous findings that CAT has a higher significant role than GPX in protecting erythrocytes against oxidative stress (Gaetani, et al.,1996) and (Muller, et al.,1997). The present data showed a marked depletion in GSH content in liver of Ehrlich solid tumor (EST) bearing mice accompanied by significant reduction in SOD and catalase activities. There is a close correlation between depletion of GSH and antioxidant enzymes and the increase in lipid peroxidation (Devi and Ganasoundari, 1999). GSH plays an important role as an endogenous antioxidant system that is found particularly in high concentration in liver and is known to have key function in protecting cells by scavenging ROS (Sinclair. et al., 1990) and (Mates, et al., 1999), modulating cellular redox status and acting as a cofactor for antioxidant enzymes (Niki, 2008), (Sen, 2000) and (Agrawal, et al., 2011). On the other hand, the free radical scavenging system, CAT and SOD are to provide a guard against the potentially injurious reactivity of superoxide and hydrogen peroxide (Rushmore and Picket, 1993), (Rajkapoor, et al., 2007) and ( Kathiriya, et al ., 2010 ). Level of GSH and antioxidant status during tumor growth was previously investigated by (Navarro, et al., 1999). Their study showed a reduction in blood glutathione redox (GSH/GSSG) in Ehrlich ascites carcinoma -bearing mice. They attributed this result to the oxidative stress that caused an elevation in peroxide formation by cancer cells. GSH oxidation occurred in the red blood cells leads to the release of GSSG from the different tissues to the blood stream ( Al Abdan, 2012). A significant reduction in SOD and catalase activities was observed in liver tissue of tumor-bearing mice. Similar results of a marked decrease in liver SOD activity was observed in plasma, lung and liver of Ehrlich carcinoma-bearing animals (AbuZeid et al., 2000) . It was reported that, Tumor development may lead to the degradation of antioxidant enzymes such as SOD and catalase as a result of uncontrolled oxidative damage (Hasegawa, et al., 1992). Malondialdehyde (MDA) the end product of lipid peroxidation acts as a marker of oxidative stress (Choi, et al ., 2012) and ( Niki , 2008). In the current study, EST bearing mice displayed a significant increase liver MDA concentration. Previous studies demonstrated that tumor growth disrupts the antioxidant system and increases LPx in tumor host vital organs (Gonenc, et al ., 2001), (Badr El-Din , 2004) and (Noaman, et al ., 2008 ). The generation of lipid peroxide and its increase in the mouse liver could result from a chain reaction or could be initiated by indirect mechanisms that have escaped the antioxidant capacity of the liver of EST bearing mice. In the present study, untreated tumor bearing mice showed significant elevation in serum ALT and AST activities and urea and creatinine concentrations as compared with control group. The obtained results indicate that, the development of tumor in the animal body can affect many functions of vital organs such as liver function. Similarly, Gupta et al., (2004) showed elevation of liver transaminases in EAC bearing mice indicating liver dysfunction. Also, (Pal, et al.,2005) demonstrated that, the activity of the liver enzymes was increased in serum of EAC-bearing mice indicating general toxicity that occurred due to cancer development. Also, liver and kidney toxicity induced during tumor growth may be due to the excessive production of ROS that leads to oxidative damage (Borges, et al., 2006). It was previously observed that oxidative damage which appeared as 
increased lipid peroxidation and inhibition of GSH content, catalase and SOD activity, led to liver and kidney dysfunctions ( $\mathrm{El}$ Nahal , 2010) . The recorded increase in plasma ALT and AST activities in tumor bearing mice of the present study might be due to generalized destruction of liver cells and release of AST into plasma after tumor induction. On the other hand, a significant increase in serum urea concentration in TBM was confirmed by the results observed by (Hussein and Azab,1997) who observed that, there was a highly significant increase in plasma urea concentration in tumor-bearing mice. The author attributed such increase in blood urea concentration to the increase in urea production as a result of catabolic effect of tumor. The obtained results showed a very highly significant increase in serum creatinine concentration in tumor bearing mice. These results were similar to (Hussein, 2003) who observed that, serum creatinine level showed a significant increase in mice-bearing Ehrlich ascites carcinoma due to muscle necrosis. As confirmed by (Kawaguchi et al., 1991) who suggested that, creatinine was increased in tumor-bearing rats as the glomerular lesions progressed, associated with a rise in serum creatinine level. Moreover, a highly significant increases showed all over the experimental period in (AST) activity (U/ml) as compared to (NTBM) administrated nanocompsite , these results were similar results reported by (Mokhtar et al., 2008) who showed that, curcumin decreased the induction of (AST and ALT) activity of rats treated with Sodium arsenite. these results were confirmed by (Tirkey et al., 2005) who showed in studies with cyclosporine that, treatment with curcumin was significantly decreased the level of urea and creatinine because of its role as potent antioxidant. These suggestion was confirmed by (Farombi and Ekor, 2006) who found that, the preventive effect of curcumin on the gentamicin-induced decrease in the activity of glutathione peroxidase (GSHPx) and CAT could contribute to the restoration of markers of renal tubular injury. It seems reasonable to assume that curcumin is able to suppress nephrotoxicity in kidney, as it was demonstrated in studies with adriamycin (Venkatesan, et al., 2000). Kanter et al., (2005) demonstrates that, Vit $\mathrm{C}$ treatment decreases serum urea and creatinine concentrations and increase antioxidant enzyme activities, and also prevents renal damage in experimentallyinduced endotoxemic rats. An important study in rats showed that TQ prevented the ischemia/reperfusion induced alterations in gastric mucosal glutathione (GSH) and superoxide dismutase (SOD) (El-Abhar, et al., 2003 ). Also, pre-treatment with TQ protected organs against oxidative damage induced by carbon tetrachloride (Nagi, et al., 1999 ) and doxorubicin (al-Shabanah, et al ., 1998 ).Moreever, another study showed that, TQ has role in the protection of organs against oxidative damage induced by a free radical generating agents (Baynes, 1991 ). Additionally, in vitro study proved that TQ and a synthetic structurally-related TBHQ, strongly inhibited iron-dependent microsomal lipid peroxidation in a concentration-dependent manner (Badary, et al., 2003). CUR significantly and dosedependently improved urea and creatinine, and decreasing the elevated levels of serum urea and creatinine provides convincing evidence for participation of reactive oxygen species (ROS) in ciplastin (cisdiammine dichloroplatinum) CDDP induced renal dysfunction. So that, CUR due to its potential antioxidants properties, improves renal function via attenuating the oxidative stress (Sumanont, et al., 2003) and ( Vajragupta, et al ., 2003) . They explained it on the antioxidant actions of Niegla Sativa (NS) which prevented the renal damage produced by reactive oxygen species (Yaman, et al., 2010). Similar findings had been reported earlier by Ali (2004) who observed that, treatment of rats with NS oil showed significant alleviation in the biochemical parameters of gentamicin nephrotoxicity, implying a rise in the scavenger de-fense system and the 
total anti-oxidant condition in kidney parenchyma. Studies performed on NS in various models of oxidative stress showed that the majority of its pharmacological effects are owing to its antioxidant potential which is chiefly a result of its capability to hunt reactive oxygen radicals and to slow down the process of lipid peroxidation (Gupta, et al., 2004). In the present study, presumably the antioxidant action of the Nigella sativa prevented the oxidative damage of renal tissue with subsequent reduction in serum levels of urea and creatinine. Studies have shown that NS seed extracts and its active constituents possess beneficial effects in kidney and liver damage caused as a result of exposure to various pharmacological agents (Ali, et al., 2003). Nigella sativa oil inhibited lipid peroxidation in liposomes and act as a scavenger of free radicals (Houghton, et al., 1995). In view of the action of Nigella sativa on lipid peroxidation and antioxidant defense system, it was also reported that administration of Nigella sativa oil in carbon tetrachloride induced toxicity in rats resulted in an improvement of the antioxidant defense system (Kanter, et al ., 2005 ).

\section{CONCLUSION \& RECOMMENDATION}

From the obtained results, it could be concluded that curcumin nanoparticles modified with basic nano black seeds (nigella sativa) and calcium ascorbate have higher antioxidant activity and protect liver and kidney from the harmful catabolic effect and oxidative damage of tumor. So we recommended by using this novel nanocomposite as prophylactic and preventive for many diseases and as adjuvant therapy in cancer treatment.

\section{REFERENCES}

Abu-Zeid, M., Hori, H., Nagasawa, H., Uto, Y., Inayama, S. 2000. Studies of methyl 2nitroimidazole-1-acetohydroxamate (KIN-804)2: effect on certain antioxidant enzyme systems in mice bearing Ehrlich ascites carcinoma Biol Pharm Bull, 23: 195-198.

Agrawal, S.S., Saraswati, S., Mathur, R., Pandey, M. 2011. Antitumor properties of boswellic acid against Ehrlich ascites cells bearing mouse Food Chem Toxicol, 49: 1924-1934 .

Al Abdan, M. 2012. Alfa-lipoic acid controls tumor growth and modulates hepatic redox state in Ehrlich ascites carcinomabearing mice. Sci World J, p: 1-6.

Ali,B.H., Blunden, G. 2003. Pharmacological and toxicological properties of Nigella sativa. Phytother Res, 17:299-305.

Ali, B.H. 2004. The effect of Nigella sativa oil on gentamicin nephrotoxicity in rats. Am J Chin Med, 32(1): 49-55 .

Al-Shabanah, O.A., Badary, O.A., Nagi, M.N., al-Gharably, N.M., al-Rikabi, A.C., alBekairi, A.M. 1998. Thymoquinone protects against doxorubicin-induced cardiotoxicity without compromising its antitumor activity. J Exp Clin Cancer Res , 17(2):193-8.

Anand, p., Nair, H.B., Sung, B., Kunnumakkara, A.B., Yaday, V.R., Tekmal, R.R., Aggarwal, B.B. 2010. Biochem pharmacol 79(3) : 330-8.

Badary, O.A., Taha, R.A., Gamal el-Din, A.M., Abdel-Wahab M.H. (2003). Thymoquinone is a potent superoxide anion scavenger. Drug Chem Toxicol, 26(2): 87-98 .

Badr El-Din, N.K. 2004. Protective role of sanumgerman against $\gamma$ irradiationinduced oxidative stress in Ehrlich carcinoma-bearing mice Nutr Res, 24: 271-291.

Baynes, J.W. 1991. Role of oxidative stress in development of complications in diabetes. Diabetes 40(4):405-12.

Borges, L.P., Nogueira, C.W., Panatieri, R.B., Rocha, J.B., Zeni, G. 2006. Acute liver damage induced by 2-nitropropane in rats: effect of diphenyl diselenide on antioxidant defenses. Chem Biol Interact, 160(2):99-107.

Cameron E, Pauling L, Leibovitz B. 1979. Ascorbic acid and cancer: A review. Cancer Res, 39:663-681.

Chen Q, Espey MG, Krishna MC, Mitchell JB, Corpe CP, Buettner GR, Shacter E, Levine M. 2005. Pharmacologic ascorbic acid concentrations selectively kill 
cancer cells: Action as a pro-drug to deliver hydrogen peroxide to tissues. Proc Natl Acad Sci USA, 102:1360413609.

Choi, S.K, Zhang, X.H, Seo, J.S. 2012. Suppression of oxidative stress by grape seed supplementation in rats. Nutr Res Prac ,6:3-8.

Devi, P.U, Ganasoundari, A. 1999. Modulation of glutathione and antioxidant enzymes by (Ocimum sactum) and its role in protection against radiation injury. Indian J Exp Biol 37:26-28

El-Abhar, H.S., Abdallah, D.M., Saleh, S. 2003. Gastroprotective activity of Nigella sativa oil and its constituent, thymoquinone, against gastric mucosal injury induced by ischaemia/reperfusion in rats $\mathrm{J}$ Ethnopharmacol, 84(2-3):251-8.

El-Nahal, D.M. 2010. Effect of using pectin on lead toxicity. J. American Science., 6(12):441-554.

Farombi, E.O., Ekor, M. .2006. Curcumin attenuates gentamicin-induced renal oxidative damage in rats .Food Chem. Toxicol. 44:1443-1448.

Fiumara A, Belfiore A, Russo G, Salomone E, Santonocito GM, Ippolito O, Vigneri R, Gangemi P. 1997. In situ evidence of neoplastic cell phagocytosis by macrophages in papillary thyroid cancer. J Clin Endocrinol Metab, 82:1615-1620.

Gaetani, G.F., Ferraris, A.M., Rolfo, M., Mangerini, R., Arena, S.and Kirkman, H.N. 1996. Predominant role of catalase in the disposal of hydrogen peroxide within human erythrocytes, Blood. 87:1595-1599.

Gonenc, A., Ozkan, Y., Torun, M., Simsek, B. 2001. Plasma malondialdehyde (MDA) levels in breast and lung cancer patients, J Clin Pharm Ther, $26: 141-144$.

Gupta, M., Mazumder, U.K., Kumar, T.S., Gomathi, P.P., Kumar, R.S. 2004. Antioxidant and Hepatoprotective Effects of Bauhinia racemosaagainst Paracetamol and Carbon Tetra - chloride Induced Liver Damage in Rats. IJPT, 3:12-20.

Gupta, M., Mazumder, U.K., Kumar, R.S., Kumar, T.S. 2004. Antitumor activity and antioxidant role of Bauhinia racemosa against Ehrlich ascites carcinoma in Swiss albino mice Acta Pharmacol Sin, 25(8): 1070-1076.
Hasegawa, T., Kaneko, F., Niwa, Y. 1992. Changes in lipid peroxide levels and activity of reactive oxygen scavenging enzymes in skin, serum and liver following UVB irradiation in mice Life Sci, 50:1893-1903.

Hayat, M.S. 2001. Effect of insitol hexaphosphate (IP6) on the activity of antioxidant defense system in mice loaded with solid tumor. Egyptian Journal of biochemistry and molecular biology, 24:137-153.

Houghton, P.J., Zarka, R., De Las Heras, B., Hoult, R.S. 1995. Fixed oil of Nigella sativa and derived thymoquinone inhibit eicosanoid generation in leukocytes and membrane lipid peroxidation. Planta Med, 61:33-36.

Hussein, S.A. 2003. Clinical biochemistry interpretation and applications. First Edition (Text Book).

Hussein, S.A., Azab, M.E. 1997. Effect of insulin treatment on some metabolic changes on experimentally induced tumor in female mice.The Egyptian $\mathrm{J}$.of Biochemistry ,15 (51) : 61-80.

Jemal, A., Bray, F., Center, M.M., Ferlay, J., Ward, E., Forman, D. February 2012. "Global cancer statistics". CA: a cancer journal for clinicians 61(2) 69-90.

Kakkar, P., B. Das and P.N. Viswanathan, 1984. A modified spectrophotometric assay of superoxide dismutase. Indian J. Biochem. Biophys., 21:130-132.

Kaminogawa S, Nanno M. 2004. Modulation of immune functions by food. Evid Based Complement Alternat Med, 1:241-250.

Kanter, M., Coskun, O., Armutcu, F., Uz, Y.H., Kizilay, G. 2005. Protective effect of vitamin $\mathrm{C}$, alone or in combination with vitamin $\mathrm{A}$, on endotoxin-induced oxidative renal tissue damage in rats.Tohoku J. Exp. Med., 206(2): 155162.

Kanter, M., Demir, H., Karakaya, C., Ozbek, H. 2005. Gastroprotective activity of Nigella sativa Loil and its constituent, thymoquinone against acute alcohol induced gastric mucosal injury in rats. World J Gastroenterol, 11(42): 6662-6.

Kaplan, L.A., Pesce, A.J, editors. 1984. Urea. Clin. Chem. The C.V. Mosby Co. St Louis. Toronto. Princeton,1257-1260 and 437 and 418. 
Kathiriya, A., Das, K., Kumar, E.P., Mathai, K.B. 2010. Evaluation of antitumor and antioxidant activity of Oxalis corniculata Linn. Against Ehrlich ascites carcinoma on mice Iran J Cancer Prev, 4:157-165.

Kawaguchi, H., Itoh, K., Mori, H., Hayashi, Y., Makino, S. 1991. Renal pathology in rats bearing tumor-secreting growth hormones. Pediatr Nephrol- 5(4): 533-8.

Kirkman, H.N. 1996. Predominant role of catalase in the disposal of hydrogen peroxide within human erythrocytes. Blood. 87:1595-1599.

Kulcsár G. 2003. Experimental evidence for the existence of the passive antitumor defense system formed by the synergistic action of certain small substances of the circulatory system. Cancer Biother Radiopharm, 18:949-963.

Kumaraguruparan, R., Subapriya, R., Kabalimoorthy, J., Nagini S. 2002. Antioxidant profile in the circulation of patients with fibroadenoma and adenocarcinoma of the breast. Clin Biochem. 35:275-279.

Luck, H. 1974. In: Methods in Enzymatic Analysis 2 (Ed Bergmeyer). Academic Press New York, p 885.

Mansour, M.A., Nagi, M.N., EL-Khatib, A.S., Al-Bakairi, A.M. 2002. Effects of thymoquinone on antioxidant enzyme activities, lipid peroxidation and DT diaphorase in different tissues of mice: a possible mechanism of action. Cell Biochem Funct, 20 (2): 143-51.

Mates, J.M, Perez-Gomez, C., Nunez de Castro, I. 1999. Antioxidant enzymes and human disease Clin Biochem, 32:595-603.

Mokhtar, I., Yousef, F., El-Demerdash, M., Fatma, M.E.R. 2008. Sodium arsenite induced biochemical perturbations in rats :Ameliorating effect of curcumin. Food and Chemical Toxicology, 46: 3506-3511.

Moron MS, De Pierre JW and Vik BM. 1979. Levels of glutathione, glutathione reductase and Glutathione-S-transferase activities in rat and lung liver, Biochem. Biophys. Acta, 582: 3170-3185.

Muller, S., Riedel, H.D., Stremmel, W. 1997. Direct evidence for catalase as the predominant $\mathrm{H}_{2} \mathrm{O}_{2}$ removing enzyme in human erythrocytes. Blood. 90:49734978.
Murray, R., Kaplan, A., Rubaltelli, F.F., Hammerman, C. 1984. Aminotransferases. Clin. Chem. The C.V. Mosby Co. St Louis. Toronto, Princeton, 1112-119.

Murray, R.L., Kaplan, L.A., Pesce, A.J. 1984. Creatinine In: Clinical Chemistry; Theory, Analysis and Correlation. CV Mosby Co., St. Louis, 1247-1253.

Musa, D., Dilsiz, N., Gumushan, H., Ulakoglu, G., Bitiren, M. 2004. Antitumor activity of an ethanol extractof Nigella sativaseeds. Biol Bratislava, 59(6):73540

Nagi, M.N., Alam, K., Badary, O.A., AlShabanah, O.A., Al-Sawaf, H.A., AlBekairi,A.M. 1999. Thymoquinone protects against carbon tetrachloride hepatotoxicity in mice via an antioxidant mechanism. Biochem Mol Biol Int ,47(1):153-9

Navarro, J., Obrador, E., Carretero, J., Petschen, I., Avino, J., Perez, P., 1999. Changes in glutathione status and the antioxidant system in blood and in cancer cells associate with tumor growth in vivo Free Radic Biol Med, 26: 410-418.

Niki, E. 2008. Lipid peroxidation products as oxidative stress biomarkers Biofactors, 34: 171-180.

Noaman, E., Badr El-Din, N.K., Bibars, M.A., Abou Mossallam, A.A., Ghoneum, M. 2008. Antioxidant potential by arabinoxylan rice bran, MGN-3/biobran, represents a mechanism for its oncostatic effect against murine solid Ehrlich carcinoma Cancer Lett, 268(2): 348-359.

Ohkawa H, Ohishi N, Yagi K. 1979. Assay for lipid peroxidation in animal tissues by thiobarbituric acid reaction.Annals of Biochemistry ,95:351-358.

Paglia, D.E., Valentine, W.N. 1967. Studies on the quantitative and qualitative characterization of erythrocyte glutathione peroxidase. J Lab Clin Med; 70:158-169.

Pal, S., Bhattacharyya, S., Choudhuri, T., Datta, G.K., Das, T. and Sa, G. 2005. Amelioration of immune cell number depletion and potentiation of depressed detoxification system of tumor-bearing mice by curcumin. Cancer Detect Prev. 29:470-478.

Placer, Z.A., Cushman, L., Johnson, B.C. 1966. Estimation of products of lipid 
peroxidation (malonyldialdehide) in biological fluids. Anal. Biochem., 16: 359-364.

Rahmani, A.H., Alzohairy, M.A., Khan, M.A., Aly, S.M. 2014. Therapeutic implications of black seed and its constituent thymoquinone in the prevention of cancer through inactivation and activation of molecular pathways. Evid Based Complement Alternat Med :724658

Rajkapoor, B., Sankari, M., Sumithra, M., Anbu, J., Harikrishnan, N., Gobinath, M. 2007. Antitumor and cytotoxic effects of Phyllanthus polyphyllus on Ehrlich ascites carcinoma and human cancer cell lines Biosci Biotechnol Biochem, 71(9): 2177-2183.

Rushmore, T.H., Picket, C.B. 1993. Glutathione S-transferase structure, regulation and therapeutic implication J Biol Chem, 268:11475-11478.

Saygili, E. I., Akcay, T., KonuKoglu, D., Papilla, C. 2003. Cgdem. Glutathine and glutathione-related enzymes in colorectal cancer patients. J. Toxicol. Environ. Health., 66:411-415.

Sahu, S.K., Oberley, L.W., Stevens, R.H. and Riley, E.F. 1977. Superoxide dismutase activity of Ehrlich ascities tumor cells. $J$ Natl Cancer Inst. 58:1125-1128.

Sajithlal, G.B., chithrap, chandrakassan, G. 1998. effect of curcumin on the advanced glycation and cross-linking of collagen in diabetic rats. Biochem pharmacol, 56(12): 1607-14

Salomi, N.J., Nair, S.C., Jayawardhanan, K.K., Varghese, C.D., Panikkar, K.R. 1992. Antitumour principles from Nigella sativa seeds. Cancer Lett ,63:41-6.
Sen, C.K. 2000. Cellular thiols and redoxregulated signal transduction Curr Top Cell Regul, 36: 1-30.

Sinclair, A.J., Barnett, A.H, Lunie, J. 1990. Free radical and auto-oxidant systems in health and disease $\mathrm{Br} \mathrm{J}$ Hosp Med, 43:334-344.

Steel, R., Torrie, J., Dickey, D. 1997 principles and procedures of statistics : Abiometrical Approach, 3rd ed ., McGraw - Hill, New York ,p :1-666.

Sumanont, Y., Murakami, Y., Tohda, M., Vajragupta, O., Matsumoto, K., Watanabe, H. 2004. Evaluation of nitric oxide radical scavenging activity of maganese complexes of curcumin and its derivatives. Biol Pharm Bull., 27:170173

Tirkey, N., Kaur, G., Vij, G., Chopra, K. 2005. Curcumin, a diferuloyl methane, attenuates cyclosporine-induced renal dysfunction and oxidative stress in rat kidneys. BMC Pharmacology 5: 189196.

Vajragupta, O., Boonchoong, P., Watanabe, H., Tohda, M., Kummasud, N., Sumanont, Y. 2003. Manganese complexes of curcumin and its derivatives evaluation for the radical scavenging ability and renoprotective activity. Free Radical Biol Med 35:1632--1644.

Venkatesan, N., Punithavathi, D., Arumugan, V. 2000. Curcumin prevents adriamycin nephrotoxicity in rats .Brit .J .Pharmacol 12: 31-234.

Yaman, I., Balikci E. 2010. Protective effects of Nigella sativa against gentamicin induced nephrotoxicity in rats. Exp Toxicol Pathol, 62:183-190. 